\title{
Concordantie en maatschappelijke opvattingen - deel twee
}

Dr. G.C.C. Lewin*

Het is problematisch om de maatschappelijke opvattingen als rechtsbron te gebruiken bij de vraag wanneer regelingen van de verschillende gebiedsdelen concordant moeten worden uitgelegd en wanneer niet. Bij de invulling van open normen is er een alternatieve manier waarop rekening kan worden gehouden met Caribische omstandigheden.

\section{Inleiding}

In de rechtspraak wordt bij de vraag wanneer regelingen van de verschillende gebiedsdelen van het Koninkrijk der Nederlanden concordant moeten worden uitgelegd en wanneer niet, met regelmaat verwezen naar het al dan niet bestaan van verschillen in maatschappelijke opvattingen. In een bijdrage uit 2008 heb ik betoogd dat dit problematisch is. ${ }^{1} \mathrm{Op}$ gezag van Scholten en Hartkamp heb ik toen aangenomen dat de maatschappelijke opvattingen toch nodig blijven als gezichtspunt bij de inkleuring van open normen. ${ }^{2}$ Maar nu zie ik dat anders. In paragraaf 2 wordt beschreven waarom het problematisch is de maatschappelijke opvattingen als rechtsbron te aanvaarden en waarom dit probleem alleen maar groter is geworden. In paragraaf 3 volgt een beschrijving van een alternatieve manier waarop bij de invulling van open normen rekening kan worden gehouden met Caribische omstandigheden. Paragraaf 4 bevat conclusies.

\section{Problemen rond het begrip 'maatschappelijke opvattingen'}

Zoals de bijdrage uit 2008 vermeldt, zijn de Caribische maatschappijen kleinschalig, heterogeen, pluriform en veranderlijk. Persoonlijke opvattingen van enkele opiniemakers kunnen gemakkelijk het zicht ontnemen op de opvattingen van anderen. Regelmatig zijn er veranderingen in de samenstelling van de maatschappij of andere maatschappelijke ontwikkelingen die vanwege de kleinschaligheid van de maatschappij een relatief groot effect hebben.

* Dr. G.C.C. Lewin is senior raadsheer in het Gerechtshof Amsterdam. Deze bijdrage is een bewerking van een voordracht, gehouden op 6 juli 2018 op het minisymposium 'Lokale invulling van open normen' in Curaçao.

1 G.C.C. Lewin, 'Concordantie en maatschappelijke opvattingen’, TAR-Justicia 2008, afl. 3, p. 194-199.

2 HR 6 april 1973, ECLI:NL:HR:1973:AB7188, NJ 1973/459, m.nt. G.J. Scholten (Merryweather/Hagemeyer); A.S. Hartkamp, 'De betekenis van de invoering van een nieuw vermogensrecht (boeken 3-8 NBW) in Nederland voor de rechtspraktijk in het Koninkrijk', TAR-Justicia 1991, afl. 2, p. 71-72. 
Ook zijn er problemen met de kenbaarheid van maatschappelijke opvattingen. Goed en objectief onderzoek is slechts in zeer beperkte mate voorhanden. Veel van de rechters aan wie de vaststelling van de inhoud van maatschappelijke opvattingen wordt overgelaten, zijn Europese Nederlanders die slechts een beperkt aantal jaren in het Caribische deel van het Koninkrijk verblijven.

Een cassatietechnisch probleem is de vraag of de vaststelling van de inhoud van maatschappelijke opvattingen een rechtsoordeel of een feitelijk oordeel is. Indien het een rechtsoordeel is, kan de Hoge Raad dan afgaan op het oordeel van de feitenrechter? Indien het een feitelijk oordeel is, kan de feitenrechter het dan ambtshalve geven?

In 2010 zijn de problemen met de aanvaarding van maatschappelijke opvattingen als rechtsbron groter geworden. Toen zijn immers de Nederlandse Antillen uiteengevallen. Kon Scholten in 1973 nog onbekommerd schrijven over 'Antilliaanse cassatieberoepen over vragen waarin maatschappelijke opvattingen aldaar een rol mogen spelen' en had Hartkamp in 1991 nog te maken met twee landen overzee (de Nederlandse Antillen en Aruba), thans kent het Caribische deel van het Koninkrijk vier verschillende gebiedsdelen, elk met een eigen rechtsstelsel. Kan worden volgehouden dat de BES-eilanden (Caribisch Nederland) een gezamenlijke maatschappij vormen, met eigen maatschappelijke opvattingen die niet verschillen tussen de drie BES-eilanden onderling, maar wel afwijken van die van de drie Caribische landen van het Koninkrijk? Op mij komt dat over als een gekunstelde constructie.

Overigens is sinds 2010 de eerste grondslag van het beginsel van concordantie van rechtspraak tussen de BES-eilanden en Europees Nederland gewijzigd: in artikel 39 Statuut worden deze gebiedsdelen gezamenlijk aangeduid als Nederland. Artikel 1 lid 2 Statuut vermeldt (kort samengevat) dat voor de BES-eilanden regels kunnen worden gesteld met het oog op factoren waardoor de BES-eilanden zich wezenlijk onderscheiden van Europees Nederland. De tweede grondslag van het beginsel van concordantie van rechtspraak (de gezamenlijke cassatierechter, art. 23 lid 1 Statuut jo. art. 1 lid 1 Rijkswet rechtsmacht Hoge $\mathrm{Raad}$ ) is wel dezelfde gebleven.

In 2012 zijn de problemen met de aanvaarding van maatschappelijke opvattingen als rechtsbron weer een beetje groter geworden. Toen heeft de Hoge Raad in een vooropstelling over concordantie van rechtspraak een aanscherping gegeven waarvan de betekenis misschien onvoldoende opgemerkt is gebleven. Tot dan toe mocht uit de overwegingen van de Hoge Raad worden afgeleid dat hij een uitzondering op het beginsel van concordantie van rechtspraak aanvaardde, indien blijkt dat daarvoor een rechtvaardiging zou kunnen worden gevonden in een relevant verschil tussen de maatschappelijke opvattingen op het betreffende rechtsgebied. ${ }^{3}$ In 2012 sprak de Hoge Raad echter ineens van een duidelijk verschil tussen de maatschappelijke opvattingen. ${ }^{4}$ Als iets duidelijk is, dan is het

3 HR 14 februari 1997, ECLI:NL:HR:1997:ZC2280, NJ 1999/409, m.nt. S.C.J.J. Kortmann (Zunoca/Aruba).

4 HR 19 oktober 2012, ECLI:NL:HR:2012:BX5797, NJ 2013/121, m.nt. J.H. Spoor (Diageo/Sriram). Terzijde: de 'fundamenteel verschillende maatschappelijke opvattingen' van HR 13 april 2007, ECLI:NL:HR: 2007:AZ6095, NJ 2014/50 (Oduber/Lamers) hebben geen betrekking op concordantie van rechtspraak, maar op concordantie van (formele) wetgeving. 
wel dat de verschillen tussen de maatschappelijke opvattingen niet duidelijk zijn. Het lijkt er dus op dat ook de Hoge Raad minder enthousiast is geworden over de maatschappelijke opvattingen als rechtsbron bij de beoordeling van de vraag wanneer regelingen concordant moeten worden uitgelegd en wanneer niet.

\section{Een alternatief}

Bij de invulling van open normen is er een alternatief. De gewone manier om een zaak te beslissen op basis van een open norm, is door alle ter zake dienende omstandigheden van het geval in onderling verband en samenhang in de beoordeling te betrekken. De rechter aan wie de vraag ter beantwoording voorligt of in een bepaald geval aan een bepaalde open norm is voldaan, dient daarom de relevante feiten zo uitgebreid en zo precies mogelijk op basis van het partijdebat vast te stellen, volgens de gewone techniek van stellen, betwisten en bewijzen. Bijna altijd is een relevant gezichtspunt de vraag tot welke maatschappelijke kringen partijen behoren (overheid, bedrijfsleven, consument, met talloze verdere onderscheidingen en nuanceringen) en in welke maatschappelijke sfeer het geschil zich afspeelt (in de familie, in de woonomgeving of op het werk, ook met onderscheidingen en nuanceringen). De rechter zal als vanzelf impliciet of expliciet de opvattingen die in die maatschappelijke kring en in die maatschappelijke sfeer heersen, in zijn beoordeling betrekken. Dat is zijn dagelijks werk. Hij is daar ook voor toegerust als hij zelf niet tot de desbetreffende maatschappelijke kring behoort. Door de jaren heen heeft hij een bepaald soort inlevingsvermogen ontwikkeld dat hem daartoe in staat stelt. Dat is in het Europese deel van het Koninkrijk zo en dat is in het Caribische deel van het Koninkrijk niet anders. Het geldt zowel voor de rechter die rechtspreekt in de streek waar hij geboren en getogen is, als voor de rechter die dat elders doet. Daarmee is het probleem voor een deel opgelost.

Het kan echter voorkomen dat de rechter meent dat er Caribische maatschappelijke omstandigheden zijn die voor een juiste beoordeling van de zaak van belang zijn, die in de Caribische context zo vanzelfsprekend zijn dat partijen ze ongenoemd hebben gelaten, maar waarvan niet zonder meer kan worden aangenomen dat de cassatierechter in Den Haag er ook mee bekend is. In een dergelijk geval kan de rechter mijn inziens beter niet maatschappelijke opvattingen erbij halen, maar feiten van algemene bekendheid, dat wil zeggen: feiten die in het Caribische deel van het Koninkrijk van algemene bekendheid zijn, maar in het Europese deel misschien niet. Een bekend voorbeeld geeft de volgende overweging:

'Het is van algemene bekendheid dat een tegelvloer bij of na regen zo glad kan zijn dat iemand die daarover loopt het gevaar loopt ten val te komen. Bij mensen die vertrouwd zijn met het klimaat in Aruba, waarin na perioden van droogte hevige regen kan vallen, is van algemene bekendheid dat men in Aruba terdege met dit gevaar rekening moet houden. ${ }^{5}$ 
Een ander voorbeeld:

'Het is een feit van algemene bekendheid dat men in de Nederlandse Antillen op grote schaal, in elk geval in het verleden, vee (in het bijzonder geiten) liet grazen op dit soort open overheidsgrond en ook anderszins die grond gebruikte. ${ }^{6}$

Dergelijke overwegingen hebben het technische voordeel dat zij goed in het cassatiestelsel passen: de feitenrechter kan ze ambtshalve vaststellen en de Hoge Raad dient ze (als feitelijke oordelen) terughoudend te toetsen, namelijk niet op juistheid, maar op begrijpelijkheid. ${ }^{7} \mathrm{Zij}$ hebben bovendien het voordeel dat de rechter zich wat minder ostentatief op het gladde en dunne ijs begeeft van ongeschreven regels over wat 'de maatschappij' ergens van vindt.

Daarmee is het probleem voor nog een deel opgelost. Blijft er een deel over waarvoor het probleem niet is opgelost?

Wat als de rechter het volgende denkt:

'Deze casus speelt zich af in het Caribische deel van het Koninkrijk. Ik (rechter) meen dat de beslissing anders moet luiden dan indien deze casus zich in Europees Nederland zou hebben afgespeeld onder voor het overige precies dezelfde omstandigheden. Maar ik kan niet concreet aanwijzen dat de feitelijke situatie in het Caribische deel van het Koninkrijk in een relevant opzicht anders is dan in Europees Nederland. Ik concludeer dat in het Caribische deel van het Koninkrijk anders over dit onderwerp wordt gedacht dan in Nederland.'

Zijn er dergelijke gevallen? Zo ja, dan moet de rechter in die gevallen zo precies mogelijk de Caribische rechtsovertuiging formuleren die volgens de rechter afwijkt van de rechtsovertuiging in Europees Nederland op het desbetreffende gebied. Ik denk dat de ruimte daarvoor beperkt is. De verschillende rechtsstelsels in het Koninkrijk zijn immers sterk aan elkaar verwant.

\section{Conclusies}

Het is problematisch om de maatschappelijke opvattingen als rechtsbron te gebruiken bij de vraag wanneer regelingen van de verschillende gebiedsdelen concordant moeten worden uitgelegd en wanneer niet. Dit geldt ook bij de invulling van open normen.

Er is een alternatieve manier waarop bij de invulling van open normen rekening kan worden gehouden met Caribische omstandigheden. Ten eerste kan de rechter bij de vaststelling van de relevante omstandigheden van het geval de vraag betrekken tot welke maatschappelijke kringen partijen behoren en in welke maatschappelijke sfeer het geschil zich afspeelt. Ten tweede kan de rechter feiten vaststellen die in het Caribische deel van het 
Koninkrijk van algemene bekendheid zijn, maar in het Europese deel misschien niet. De ruimte om ook afwijkende rechtsovertuigingen vast te stellen is echter beperkt. 